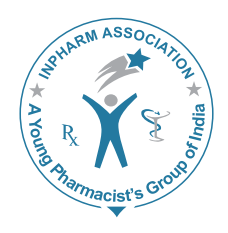

\title{
Iso-6-spectaline effects on convulsions induced in epilepsy models
}

\author{
Silva FO, Silva MGV, Cerqueira GS', Sabino EB², Almeida AAC ${ }^{2}$, \\ Costa JP2, Freitas RM² \\ Department of Organic and Inorganic Chemistry of Federal University of Piaui, CEP 64.049-550, Teresina, \\ Piaui, ${ }^{1}$ Department of Physiology and Pharmacology of Federal University of Ceará, \\ CEP: 60.430-270, Fortaleza, Ceará, ${ }^{2}$ Department of Biochemistry and Pharmacology, Post-Graduation \\ Program in Pharmaceutics Science of Federal University of Piaui, CEP 64.049-550, Teresina, Piaui, Brazil.
}

Address for correspondence: Dr. Rivelilson Mendes de Freitas; E-mail: rivelilson@pq.cnpq.br

\begin{abstract}
The central nervous system (CNS) and anticonvulsant activities of iso-6-spectaline (SPEC) from Senna spectabilis were investigated in animal models. The SPEC from Senna spectabilis var. excelsa (Schrad) (0.1, 0.5 and $1.0 \mathrm{mg} / \mathrm{kg}$ ) injected by oral route (p.o.) in mice caused a significant decrease in the motor activity up to $24 \mathrm{~h}$ after the administration and in the dose of $1.0 \mathrm{mg} / \mathrm{kg}$ significantly reduced the remaining time on the Rota-rod apparatus. Additionally, SPEC (0.1, 0.5 and $1.0 \mathrm{mg} / \mathrm{kg}$, p.o.) was also capable of promoting increase of latency for development of convulsions induced by pentylenetetrazole. This SPEC was also capable of promoting an increase of latency for development of convulsions induced by picrotoxin (PIC) only at highest dose. In the same way, the anticonvulsant effect of SPEC was affected by pretreatment with flumazenil, a selective antagonist of the benzodiazepine site of the $G_{A B A}$ receptor. These results suggest possible anticonvulsant activities in mice that needs further investigation.
\end{abstract}

Key words: Fabaceae, open field, pentylenetetrazole, picrotoxin, senna spectabilis

\section{INTRODUCTION}

Several herbal medicines are recognized as active in the central nervous system (CNS), and they have at least a hypothetical potential to affect neurodegenerative conditions including epilepsy, that do not respond well to conventional

\begin{tabular}{|l|l|}
\hline \multicolumn{2}{|c|}{ Access this article online } \\
\hline Quick Response Code: & \\
\hline & Website: \\
& www.jyoungpharm.in \\
& \\
\hline
\end{tabular}

treatments. Thus, iso-6-spectaline (SPEC) may possess a neuromodulatory role in the treatment of seizures, since this piperidine alkaloid compound can interrupt cellular oxidative processes and monoaminergic system changes in the hippocampus and striatum. The effects of SPEC on these cerebral areas have not yet been determined, therefore, would be important to conduct these studies to clarify its brain action mechanism.

Piperidine alkaloids are abundant in nature and many of them are known to exhibit some biological activity. In our search for potential anxiolytic, antidepressant or anticonvulsant agents employing a mechanismbased yeast bioassay for CNS-modifying agents, ${ }^{[1]}$ 
we have isolated iso-6-spectaline (SPEC; 14-[(2R,3R,6R) -3-hydroxy -2-methylpiperidine]-tetradecan-13-one), piperidine alkaloids, is a heterocyclic organic not aromatic compound [Figure 1] found in many plant species. It was isolated for the first time from Cassia sp., species previously known as Cassia excelsa, hence the term cassine. ${ }^{[2]}$ Piperidine alkaloid derivatives with CNS effects include SPEC which exerts neuroprotective effects against depression model. ${ }^{[2]}$

Senna spectabilis is used as anti-inflammatory, analgesic, laxative, purgative, antimicrobial and antiulcerogenic. ${ }^{[3-5]}$ Studies have shown that the extract of Senna sp. inhibits excessive production of free radicals, and the imbalance between the concentrations of these and the antioxidant defenses may be related to the pathogenesis of seizures. ${ }^{[6-8]}$

The genus Cassia possesses about 600 species distributed worldwide, being well known due to its diverse biological and pharmacological properties. ${ }^{[4]}$ Senna spectabilis (DC) Irwin and Barneby var. spectabilis (Cassia spectabilis DC) is widely grown as an ornamental plant in tropical and subtropical areas, and has been commonly used in traditional medicine for many years. It has also been used in traditional Brazilian medicine for the treatment of flu and cold, as a laxative and purgative..$^{[9,10]}$

Previous studies about behavioral screening realized with the SPEC demonstrates that it produces antioxidant effects in vitro and reduces lipid peroxidation in hippocampus of adult mice after pilocarpine-induced seizures, increasing survival rate and reducing number of seizures in mice. Additionally, there is no work demonstrating SPEC effects in neurodegenerative diseases in animal on epilepsy models.

\section{MATERIALS AND METHODS}

\section{Plant material and chemistry study}

The plant was collected in September 2003, at Boa Viagem, State of Ceará, Brazil, and was identified by Prof. A.G. Fernandes, in the Department of Biology of

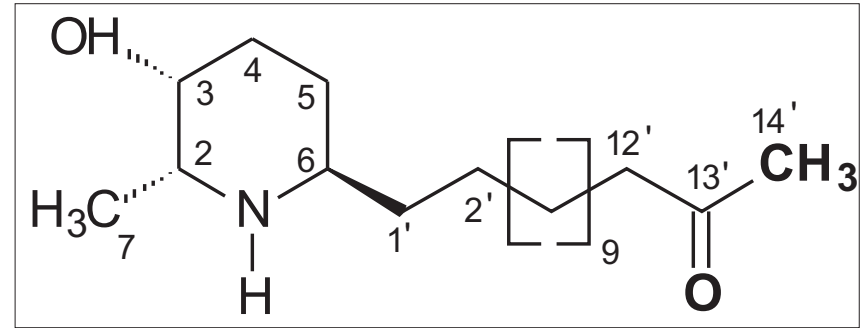

Figure 1: Chemical structure of iso-6-spectaline (SPEC; 14-[(2R,3R,6R)3-hydroxy-2-methylpiperidine]-tetradecan-13-one) the Federal University of Ceará. The voucher specimen is deposited at the Prisco Bezerra Herbarium under the voucher number 33013.

The botanical material, leaves $(3.0 \mathrm{~kg})$, stem $(10.2 \mathrm{~kg})$ and roots $(7.6 \mathrm{~kg})$, were triturated and exhaustingly extracted with ethanol and concentrated in rotative evaporator, producing $78 \mathrm{~g}, 55 \mathrm{~g}$ and $84 \mathrm{~g}$ respectively. The leaf extract $(78 \mathrm{~g})$ was then submitted to technical of selective extraction of alkaloids a fraction rich in alkaloids (FA) and a non alkaloids (FNA) were obtained. The alkaloid fraction was submitted to chromatography on SEPHADEX, with methanol as movable phase. The dichloromethane fraction $(15.2 \mathrm{~g})$ was submitted to the same chromatography process.

The analysis of the fractions was made in chromatography in thin layer (CCD), which revealed the purity of the rich fraction in SPEC (30 mg) which when subjected to the test with the reagent Dragendoff revealed an orange stain, and was thus positive for alkaloids. ${ }^{[1]]}$ Its spectra of NMR RMN ${ }^{1} \mathrm{H}, \mathrm{RMN}^{13} \mathrm{C}$, DEPT 135, COSY, HMBC e $\mathrm{HSQC}^{1}$ were obtained and compared with the data from the literature for identification. The iso- 6 -spectaline is an amorphous white solid with M.P. $130.8-132.3^{\circ} \mathrm{C}$; the value of TLC in $\mathrm{MeOH} / \mathrm{EtOAc}(1: 1), \mathrm{Rf}=0.58$; NMR spectra description of ${ }^{1} \mathrm{H}$ is ${ }^{1} \mathrm{H}$ NMR (MeOD, $\left.500 \mathrm{MHz}\right) \delta_{H} 3.83$ (1H, H-3); 3.30 (1H, H-6); 3.23 (1H, H-2); 2.47 (2H, H-12); 2.15 (3H, H-14); 1.44 (3H, H-7); 1.29-1.33 (12H, H-4' $\mathrm{H}-9$ ); NMR spectra description of ${ }^{13} \mathrm{C}$ is ${ }^{13} \mathrm{C}$ NMR (MeOD, $125 \mathrm{MHz}) \delta_{C}-212.4(\mathrm{C}, \mathrm{C}-13) ; 66.1(\mathrm{CH}, \mathrm{C}-3) ; 58.8(\mathrm{CH}$, C-2); 57.7 (CH, C-6); $44.4\left(\mathrm{CH}_{2}, \mathrm{C}-12\right) ; 34.9\left(\mathrm{CH}_{2}, \mathrm{C}-1\right)$; $31.2\left(\mathrm{CH}_{2}, \mathrm{C}-4\right) ; 29.9\left(\mathrm{CH}_{3}, \mathrm{C}-14\right) ; 30.9\left(\mathrm{CH}_{2}, \mathrm{C}-3\right) ; 30.5$ $\left(\mathrm{CH}_{2}, \mathrm{C}-10\right)$; 30.5-30.9 $\left(\mathrm{CH}_{2}, \mathrm{C}-4-\mathrm{C}-9\right) ; 26.4\left(\mathrm{CH}_{2}, \mathrm{C}-2\right)$; $23.8\left(\mathrm{CH}_{2}, \mathrm{C}-5\right) ; 23.8\left(\mathrm{CH}_{2}, \mathrm{C}-11\right) ; 16.1\left(\mathrm{CH}_{3}, \mathrm{C}-7\right)$. In the present work, the iso- 6 -spectaline was suspended in $0.5 \%$ Tween 80 distilled in water, and sonicated before use. Agents were administrated orally (p.o.) and intraperitoneally (i.p.) at a dose volume of $0.1 \mathrm{ml} / 10 \mathrm{~g}$.

\section{Animals}

Male Swiss mice (25-30 g), two months of age were used. The animals were randomly housed in appropriate cages at $23 \pm 2^{\circ} \mathrm{C}$ on a 12-h light/dark cycle (lights on 08:00 a.m. $-18: 00$ p.m.) with free access to food $\left(\right.$ Purina $\left.^{\circledR}\right)$ and water. All experiments were carried out between 08:00 a.m. and 18:00 p.m. in a quiet room. Experimental protocols and procedures were approved by the Ethics Committee on Animal Experiments at the Federal University of Piaui (CEEA/UFPI \# 44/09). 
Behavioral effects, locomotor activity and motor coordination test (rota-rod test)

Behavioral screening ( $n=7$, per group) was performed following parameters described by Almeida et al., ${ }^{[12]}$ and animals were observed at 14 days after oral (p.o.) administration of SPEC (0.1, 0.5, and $1.0 \mathrm{mg} / \mathrm{kg}$, p.o.).

Mice were divided into four groups (seven animals each). Vehicle (saline/Tween 80 0.5\%; control group) and SPEC $(0.1,0.5$, and $1.0 \mathrm{mg} / \mathrm{kg}$, p.o.) were injected. The spontaneous locomotor activity of the animals was assessed in a cage activity $(50 \mathrm{~cm} \times 50 \mathrm{~cm} \times 50 \mathrm{~cm})$ after $24 \mathrm{~h}$ of treatment. ${ }^{[13]}$

A Rota-rod treadmill device (AVS ${ }^{\circledR}$, Brazil) was used for the evaluation of motor coordination. ${ }^{[14]}$ Initially, the mice able to remain on the Rota-rod apparatus longer than $180 \mathrm{~s}$ (16 rpm) were selected $24 \mathrm{~h}$ before the test. Thirty minutes after $24 \mathrm{~h}$ of administration of either SPEC $(0.1,0.5$, and 1.0 $\mathrm{mg} / \mathrm{kg}$, p.o.), vehicle (saline/Tween 80 0.5\%; control group) or diazepam (DZP, $2.0 \mathrm{mg} / \mathrm{kg}$, i.p.), each animal was tested on the Rota-rod apparatus and the time(s) remained on the bar for up to $180 \mathrm{~s}$ was recorded after $24 \mathrm{~h}$ of treatment.

\section{Pentylenetetrazole-induced convulsions}

Pentylenetetrazole (PTZ) $(60 \mathrm{mg} / \mathrm{kg}$, i.p.) was used to induce clonic convulsions. ${ }^{[15]}$ Mice were divided into five groups ( $n=7$ per group). First group received vehicle (two drops of Tween $800.5 \%$ in distilled water, the solvent for SPEC) while the second group was treated with diazepam (DZP, $2.0 \mathrm{mg} / \mathrm{kg}$, i.p.). The remaining groups received an injection of SPEC (0.1, 0.5, and $1.0 \mathrm{mg} / \mathrm{kg}$, p.o.). After $24 \mathrm{~h}$ of drug administration, the mice were treated with PTZ (i.p.) at a dose of $60 \mathrm{mg} / \mathrm{kg}$. The latency and percentage of inhibition clonic convulsions were registered. The incidence of deaths was noted until $24 \mathrm{~h}$ after the injection of PTZ.

The effect of selective $\mathrm{GABA}_{\mathrm{A}}-\mathrm{BZD}$ receptor antagonist flumazenil ${ }^{[16]}$ on the anticonvulsant activity of SPEC was investigated. In the experimental groups, mice were given flumazenil (FLU) $(10 \mathrm{mg} / \mathrm{kg}$, i.p.) $30 \mathrm{~min}$ before the administration of SPEC (1.0 mg/kg, p.o.) $(24 \mathrm{~h}$ before the injection of PTZ). In the standard group, the animals received FLU $30 \mathrm{~min}$ before the administration of diazepam (DZP, $2.0 \mathrm{mg} / \mathrm{kg}$, i.p.) (24 h before the injection of PTZ). The anticonvulsant activity of SPEC and DZP in mice pretreated with FLU was assessed.

\section{Picrotoxin-induced convulsion}

The method has been described previously. ${ }^{[17,18]}$ Animals were divided into five groups ( $n=7$ per group). Control group received vehicle and standard group was treated with diazepam (DZP, $2.0 \mathrm{mg} / \mathrm{kg}$, i.p.). The remaining groups were treated with 0.1, 0.5 and $1.0 \mathrm{mg} / \mathrm{kg}$ (p.o.) of SPEC. After 24 $\mathrm{h}$ of drug administration, the mice were treated with PIC at a dose of $8 \mathrm{mg} / \mathrm{kg}$ (i.p.). Immediately after the injection of the convulsant, mice were individually placed in plastic boxes and observed for the time to onset of clonic convulsion (latency), percent clonic convulsion and deaths. The incidence of deaths was noted until $24 \mathrm{~h}$ after the injection of PIC.

\section{Statistical analysis}

The data obtained were evaluated by one-way analysis of variance (ANOVA) followed by Student-NeumanKeuls $t$-test. The incidence (\%) of clonic or tonic-clonic convulsions as well as the mortality were evaluated by Fisher`s Exact Test. Differences were considered to be statistically significant when $P<0.05$.

\section{RESULTS AND DISCUSSION}

Analysis of the ${ }^{1} \mathrm{H}$ NMR and ${ }^{13} \mathrm{C}$ NMR spectra showed that SPEC presented analytical and spectroscopic data in full agreement with its assigned chemical structure [Figure 1]. The chemical purity of the compound was determined by analysis of the ${ }^{1} \mathrm{H}$ NMR and ${ }^{13} \mathrm{C}$ NMR.

SPEC at doses of $0.1,0.5$ and $1.0 \mathrm{mg} / \mathrm{kg}$ (p.o.) showed behavioral changes in animals $24 \mathrm{~h}$ after of treatment: Decrease of spontaneous activity, palpebral ptosis, ataxia and analgesia. Behavioral changes were more evident on the second day of treatment. The doses of $0.1,0.5$ and $1.0 \mathrm{mg} /$ $\mathrm{kg}$ (p.o.) of SPEC caused significant decrease of 30\%, 30\% and $59 \%$ of ambulation (number of crossings) $24 \mathrm{~h}$ after administration, respectively [Figure 2]. In this test only the highest dose (1.0 mg/kg, p.o.) reduced (40\%) the remaining time of animals on the Rota-rod apparatus [Figure 3].

Table 1 shows that (PTZ) consistently induced clonic

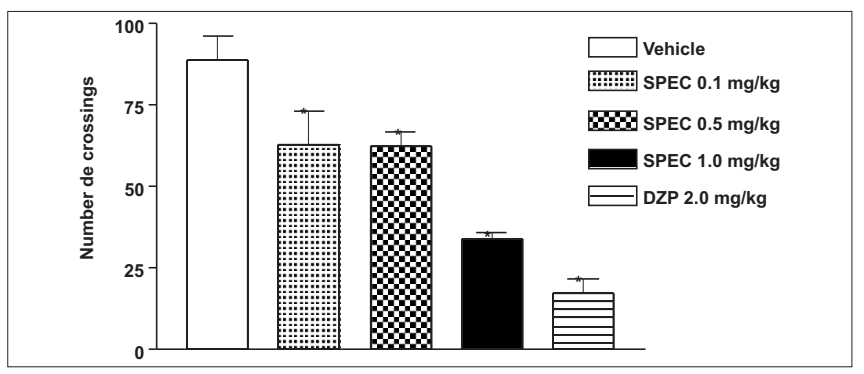

Figure 2: Effects of iso-6-spectaline $(0.1,0.5$ and $1.0 \mathrm{mg} / \mathrm{kg}$, p.o., SPEC) or diazepam (DZP, $2.0 \mathrm{mg} / \mathrm{kg}$, i.p.) on locomotor activity of mice. The parameters evaluated were the total number of pulses of crossings in activity cage. Values are mean \pm S.E.M. for seven mice per group. ${ }^{*} P<0.001$ as compared to control (Vehicle), one-way ANOVA followed by Student-Neuman-Keuls $t$-test 


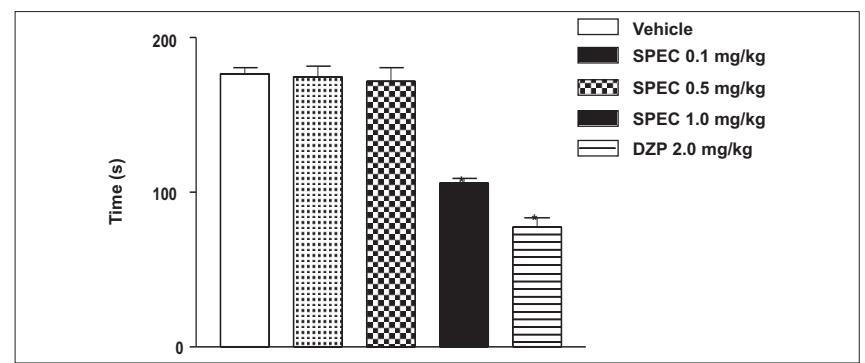

Figure 3: Time (s) on the Rota-rod observed in mice after oral route treatment with Vehicle (control), iso-6-spectaline $(0.1,0.5$ and $1.0 \mathrm{mg} / \mathrm{kg}$, p.o., SPEC) or DZP (2.0 mg/kg, i.p.). The motor response was recorded for the following $180 \mathrm{~s}$ after drug treatment. Values are mean \pm S.E.M. for seven mice per group. ${ }^{*} P<0.001$ as compared to control (Vehicle), one-way ANOVA followed by Student-NeumanKeuls $t$-test

convulsions in $100 \%$ of mice. SPEC (0.1, 0.5 and $1.0 \mathrm{mg} / \mathrm{kg}$, p.o.) delayed the onset of PTZ-induced tonic convulsion significantly and $(1.0 \mathrm{mg} / \mathrm{kg}$, p.o.) protected $80 \%(P<0.001)$ of mice against the convulsion and reduced in 30\% the mortality rate in PTZ model. Diazepam completely protected the animals against the tonic convulsion elicited by PTZ.

As described in Table 1, the administration of FLU (10 $\mathrm{mg} / \mathrm{kg}$, i.p.) antagonized the effect of SPEC $(1.0 \mathrm{mg} /$ $\mathrm{kg}$, i.p.) and DZP ( $2 \mathrm{mg} / \mathrm{kg}$, i.p. $)$ in the prolongation of convulsion latency. When given i.p., only the highest dose of SPEC $(1.0 \mathrm{mg} / \mathrm{kg}$, i.p.) increased the latency for convulsions and reduced in 50\% the mortality rate in PIC model induced by PIC significantly when compared to the control $(P<0.001)$ [Table 2].

The anticonvulsants effects of SPEC isolated from $S$. spectabilis were emphasized in the present work since the management of neurodegenerative diseases faces a number of problems including limited number of effective antidepressant agents and toxicity of the available anticonvulsant agents. Previous studies showed that Senna spectabilis is used as an anti-inflammatory, analgesic, laxative, purgative, antimicrobial and antiulcerogenic by popular medicine in Brazil. ${ }^{[3,4]}$ In neuropharmacological behavioral screening, the animals treated with SPEC showed decrease of response to the touch, palpebral ptosis, ataxia and analgesia. These results suggest that SPEC could exert a depressive activity in rodents. ${ }^{[2]}$ indicating effects on the CNS similar to iso-6-cassine isolated from Senna spectabilis var. excelsa (Schrad) in mice and others drugs that reduce the brain function. ${ }^{[5,10,19-23]}$

The reduction of the locomotor activity observed after treatement with SPEC an be due to either an inhibitory effect of the SPEC in the CNS or by muscular relaxant activity in the periphery. Our results suggest that SEPC could show a
Table 1: Effects of iso-6-spectaline (0.1, 0.5 and 1.0 $\mathrm{mg} / \mathbf{k g}$, o.r., SPEC) on PTZ-induced convulsion in mice

\begin{tabular}{lcccc}
\hline Treatments & $\begin{array}{c}\text { Dose } \\
(\mathbf{m g} / \mathbf{k g})\end{array}$ & Latency (s) & $\begin{array}{c}\text { \% Inhibition } \\
\text { of Convulsion }\end{array}$ & $\begin{array}{c}\text { \% Inhibition of } \\
\text { Death }\end{array}$ \\
\hline Vehicle & - & 156.311 .9 & 0 & 0 \\
SPEC 0.1 & 0.1 & $279.0 \pm 22.6^{\mathrm{a}}$ & 0 & 0 \\
SPEC 0.5 & 0.5 & $376.8 \pm 38.0^{\mathrm{b}}$ & 10 & $20^{\mathrm{e}}$ \\
SPEC 1.0 & 1.0 & $582.5 \pm 33.5^{\mathrm{c}}$ & $80^{\mathrm{d}}$ & 30 \\
SPEC + FLU & $1.0+10$ & $271.8+38.9$ & 0 & 10 \\
DZP & 2 & $862.9 \pm 10.0^{\mathrm{c}}$ & $100^{\mathrm{d}}$ & $100^{\mathrm{d}}$ \\
DZP + FLU & $2+10$ & $171.2+15.2$ & 0 & 15 \\
\hline
\end{tabular}

Values are the mean \pm S.E.M. for 7 mice (per group). ${ }^{\mathrm{a}} \mathrm{p}<0.05$ (ANOVA followed by t-Student-Neuman-Keuls test), significantly different from control. ${ }^{\mathrm{b}} P<0.01$ (ANOVA followed by t-Student-Neuman-Keuls test), significantly different from control. ${ }^{\mathrm{c}} P<0.001$ (ANOVA followed by t-Student-Neuman-Keuls test), significantly different from control. ${ }^{\mathrm{d}} P<0.001$ (Fisher's test), significantly different from control. ${ }^{\mathrm{e}} P<0.05$ (Fisher`s test), significantly different from control.

Table 2: Effects of iso-6-spectaline (0.1, 0.5 and $1.0 \mathrm{mg} / \mathrm{kg}$, p.0., SPEC) on PIC-induced convulsion in mice

\begin{tabular}{lcccc}
\hline Treatment & $\begin{array}{c}\text { Dose } \\
(\mathbf{m g} / \mathbf{k g})\end{array}$ & Latency $(\mathbf{s})$ & $\begin{array}{c}\text { \% inhibition } \\
\text { of convulsion }\end{array}$ & $\begin{array}{c}\% \text { inhibition } \\
\text { of death }\end{array}$ \\
\hline Vehicle & - & $516.2 \pm 14.5$ & 0 & 0 \\
DZP & 2 & $1336.0 \pm 10.0^{\mathrm{a}}$ & $100^{\mathrm{a}}$ & $100^{\mathrm{a}}$ \\
SPEC 0.1 & 0.1 & $518.5 \pm 21.01$ & 0 & 0 \\
SPEC 0.5 & 0.5 & $517.5 \pm 45.9$ & 10 & 10 \\
SPEC 1.0 & 1.0 & $1125.9 \pm 29.3^{\mathrm{a}}$ & $50^{\mathrm{a}}$ & $50^{\mathrm{a}}$ \\
\hline
\end{tabular}

Values are mean \pm S.E.M. $\left(\mathrm{n}=7\right.$ per group). ${ }^{\mathrm{a}} P<0.05$ (ANOVA followed by Student-Neuman-Keuls $t$-test) compared to control; ${ }^{\mathrm{b}} P<0.001$ (Fisher`s test) compared to control

neuro-sedative activity or a profile for a hypnotic drug. The results of present study no suggest these effects.

Our results suggest that the higher dose of SPEC produces loss of motor coordination in mice. Thus, the lack of motor coordination is characteristic of a drug that reduces the CNS activity such as anxiolytics, sedatives and hypnotics. ${ }^{[12,24,25]}$

Data from this study show that the onset of tonic-clonic convulsion produced by PTZ was significantly delayed by SPEC [Table 2] and mortality was significantly reduced $(P<0.001)$. Previous studies about PTZ model ${ }^{[1,26]}$ showed that this convulsivant agent may be exerting its convulsing effect by inhibiting the activity of gamma aminobutyric acid $(\mathrm{GABA})$ at gabaergic $\left(\mathrm{GABA}_{\AA}\right)$ receptors. The literature reports that $G A B A$ is the inhibitory neurotransmitter implicated in human epilepsy. The enhancement and inhibition of GABA neurotransmission will attenuate and enhance convulsion, respectively. ${ }^{[27]}$

Our results showed that SPEC delayed the occurrence of PTZ convulsion and decreased the mortality rate in mice, it is probable that it may interfere in GABAergic mechanisms to exert its anticonvulsant effect in this epilepsy model..

In order to determine the anticonvulsant effects of SPEC, a specific antagonist of the benzodiazepine site in the 
GABA-benzodiazepine receptor complex, was used in experiments. ${ }^{[16]}$

The results obtained from PTZ model in mice pretreated with flumazenil suggest that this compound could facilitate the GABAergic system activity. The significant effects on the motor coordination, in doses of $1.0 \mathrm{mg} / \mathrm{kg}$, might support this hypothesis. ${ }^{[28]}$

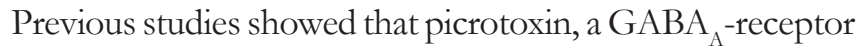
antagonist, produces seizures by blocking the chloride-ion channels, preventing the entry of chloride ions into the cerebral regions and, consequently, inhibitory transmission of central nervous system. ${ }^{[29]}$ Therefore, the findings of the present study suggest that SPEC might have inhibited attenuated the PIC-induced convulsions and reduced in 50\% the mortality rate in this epilepsy model. ${ }^{[30]}$

In conclusions, the results suggest anticonvulsant effects of iso-6-spectaline from Senna spectabilis. The possible behavioral effects produced by iso-6-spectaline are not clear, however, the GABAergic, noradrenergic and setoninergic neurotransmitter systems might be involved. So, future studies will be required for elucidation of these action mechanisms.

\section{ACKNOWLEDGMENT}

We would like to thank the National Council of Technological and Scientific Development (CNPq/Brazil), the Research Supporting Foundation of State of Piaui (FAPEPI/Brazil) for the financial support and Dr. Paulo Michel Pinheiro Ferreira (UFPI, Picos) for his help with English editing of the manuscript.

\section{REFERENCES}

1. Silva FO, Silva MG, Feng D, de Freitas RM. Evaluation of central nervous system effects of iso-6-cassine isolated from Senna spectabilis var. excelsa (Schrad) in mice. Fitoterapia 2010;82:255-9.

2. Junior CV, Rezende A, Silva DH, Castro-Gambôa I, Bolzani VS, Barreiro EJ, et al. Ethnopharmacological, biological and chemical aspects of the Cassia genus. Quim Nova 2006;29:1279-86.

3. Sansores-Peraza P, Rosado-Valladi M, Brito-Loeza W, Mena-Rejon GJ, Quijano L. Cassine, an antimicrobial alkaloid from Senna racemosa. Fitoterapia 2000;71:690-2.

4. Viegas C Jr, da S Bolzani V, Furlan M, Barreiro EJ, Young MC, Tomazela D, et al. Further bioactive piperidine alkaloids from the flowers and green fruits of cassia spectabilis. J Nat Prod 2004;67:908-10.

5. Freitas RM, Souza FC, Viana GS, Fonteles MM. Acetylcholinesterase activities in hippocampus, frontal cortex and striatum of Wistar rats after pilocarpine-induced status epilepticus. Neurosci Lett 2006;399:76-8.

6. Sunil KK, Müller K. Inhibition of leukotriene biosynthesis and lipid peroxidation in biological models by the extract of Cassia fistula. Phytother Res 1998;12:465-531.

7. Simonié A, Laginja J, Varljen J, Zupan G, Erakovié V. Lithium plus pilocarpine induced status epilepticus-biochemical changes. Neurosci Res 2000;36:157-66.

8. Freitas RM, Souza FC, Vasconcelos SM, Viana GS, Fonteles MM. Oxidative stress in the hippocampus after status epilepticus in rats. FEBS J 2005;272:1307-12.

9. Lorenzi H, Matos FJ. Plantas Medicinais do Brasil Nativas e Exóticas.
Instituto Plantarum, Nova Odessa, 2002. p. 291.

10. Carlini EA. Plants and the central nervous system. Pharmacol Biochem Behav 2003;75:501-12.

11. Mahato SB, Sen S. Advances in triterpenoid research 1990-1994. Phytochemistry 1997;44:1185-1236.

12. Almeida RN, Falcão AC, Diniz RS, Quintans-Júnior LJ, Polari RM, BarbosaFilho JM, et al. Metodologia para avaliação de plantas com atividade no sistema nervoso central e alguns dados experimentais. Rev Bras Farm 1999;80:72-6.

13. Asakura W, Matsumoto K, Ohta H, Watanbe H. Effects of alpha 2-adrenergic drugs on REM sleep deprivation-induced increase in swimming activity. Pharmacol Biochem Behav 1993;46:111-5.

14. Perez RM, Perez JA, Garcia LM, Sossa H. Neuropharmacological activity of Solanum nigrum fruit. J Ethnopharmacol 1998;62:43-8.

15. Smith M, Wilcox KS, White HS. Discovery of antiepileptic drugs. Neurotherapeutics 2007;4:12-7.

16. File SE, Pellow $S$. Intrinsic actions of the benzodiazepine receptor antagonist Ro 15-1788. Psychopharmacology (Berl) 1986;88:1-11.

17. Lehmann J, Hutchison A, McPherson SE, Mondadori C, Schmutz M, Sinton CM, et al. CGS 19755 a selective and competitive N-Metil-D-aspartate-type excitatory amino acid receptor antagonist. J Pharmacol Exp Ther 1988;246:65-75.

18. Bum EN, Schmutz M, Meyer C, Rakotonirina A, Bopelet M, Portet C, et al. Anticonvulsant properties of the methanolic extract of Cyperus articulatus (Cyperaceae). J Ethnopharmacol 2001;76:145-50.

19. Morais LC, Quintans-Júnior LJ, Franco CI, Almeida JR, Almeida RN. Antiparkinsonian-like effects of Plumbago scandens on tremorine-induced tremors methodology. Pharmacol Biochem Behav 2004;79:745-9.

20. Netto SM, Warela RW, Fechine MF, Queiroga MN, Quintans-Júnior LJ. Anxiolytic-like effect of Rawvolfia ligustrina willd. Ex Roem. and Schult. Apocynaceae, in the elevated plus-maze and hole-board tests. Braz J Pharmacogn 2009;19:888-92.

21. Freire CM, Marques MO, Costa M. Effects of seasonal variation on the central nervous system activity of Ocimum gratissimum L. essential oil. J Ethnopharmacol 2006;105:161-6.

22. Leite MP, Fassin JJ, Baziloni EM, Almeida RN, Mattei R, Leite JR. Behavioral effects of essential oil of Citrus aurantium L. inhalation in rats. Braz J Pharmacogn 2008;18:661-6.

23. Quintans-Júnior LJ, Souza TT, Leite BS, Lessa NM, Bonjardim LR, Santos MR, et al. Phythochemical screening and anticonvulsant activity of Cymbopogon winterianus jowitt (Poaceae) leaf essential oil in rodents. Phytomedicine 2008;15:619-24.

24. Dallmeier K, Carlini EA. Anesthetic, hypotermic, myorelaxant and anticonvulsant effects of synthetic eugenol derivatives and natural analogues. Pharmacology 1981;22:113-27.

25. Olayiwola G, Obafemi CA, Taiwo FO. Synthesis and neuropharmacological activity of some quinoxalinone deriv African. J Biotechnol 2007;6:777-86.

26. De Sarro A, Cecchetti V, Fravolini V, Naccari F, Tabarrini O, De Sarro G. Effects of novel 6-desfluoroquinolones and classic quinolones on pentylenetetrazoleinduced seizures in mice. Antimicrob Agents Chemother 1999;43:1729-36.

27. Westmoreland BF, Benarroch EE, Dube JR, Regan TJ, Sandok BA. Medical Neurosciences. Rochester: Mayo Foundation; 1994. p. 307.

28. Pedersen ME, Vestergaard HT, Hansen SL, Bah S, Diallo D, Jäger AK. Pharmacological screening of Malian medicinal plants used against epilepsy and convulsions. J Ethnopharmacol 2009;121:472-5.

29. Löscher W, Schmidt D. New horizons in the development of antiepileptic drugs: Innovative strategies. Epilepsy Res 2006;69:183-272.

30. Oliveira FA, de Almeida RN, Sousa MF, Barbosa-Filho JM, Diniz SA, Medeiros IA. Anticonvulsant properties of N-salicyloyltryptamine in mice. Pharmacol Biochem Behav 2001;68:199-202.

How to cite this article : Silva FO, Silva MGV, Cerqueira GS, Sabino EB, Almeida AAC, Costa JP, Freitas RM. Iso-6-spectaline effects on convulsions induced in epilepsy models. J Young Pharmacists 2011;3:232-6.

Source of Support: National Council of Technological and Scientific Development (CNPq/Brazil), the Research Supporting Foundation of State of Piaui (FAPEPI/Brazil), Conflict of Interest: None declared. 